\title{
Going Viral: A Gravity Model of Infectious Diseases and Tourism Flows
}

\section{Serhan Cevik $^{1}$ (D)}

Accepted: 2 March 2021 / Published online: 1 May 2021

(C) International Monetary Fund 2021

\begin{abstract}
This paper develops an augmented gravity model framework to estimate the impact of infectious diseases on bilateral tourism flows among 38,184 pairs of countries over the period 1995-2017. The results confirm that international tourism is adversely affected by infectious disease risk, and the magnitude of this negative effect is statistically and economically significant. In the case of SARS, for example, a $10 \%$ increase in the number of confirmed cases leads, on average, to a reduction of $4.7 \%$ in international tourist arrivals. Furthermore, while infectious diseases appear to have a smaller and statistically insignificant negative effect on tourism flows to advanced economies, the magnitude and statistical significance of the impact of infectious diseases are much greater in developing countries, where such diseases tend to be more prevalent and health infrastructure lags behind.
\end{abstract}

Keywords Infectious diseases · International tourism flows · Gravity model $\cdot$ Panel data

JEL Classification Numbers C21 · C23 · F11 · F14 · F47 · R12 · Z30

\section{Introduction}

The COVID-19 pandemic has turned into a global crisis in a staggeringly short space of time like no other in modern history. As of April 21, 2021, there are over 143 million confirmed cases of COVID-19 in 190 countries, with more than 3 million deaths. ${ }^{1}$ The widespread containment and mitigation measures designed to slow the spread of the

\footnotetext{
${ }^{1}$ The latest figures can be found at John Hopkins University's Center for Systems Science and Engineering: https://www.arcgis.com/apps/opsdashboard/index.html\#/bda7594740fd40299423467b48e9ecf6.
}

Serhan Cevik

scevik@imf.org

1 International Monetary Fund, 700 19th Street, NW, Washington, DC 20431, USA 
coronavirus have severely affected international travel and tourism, which had become a leading engine economic growth and the major source of foreign exchange earnings in many countries across the globe (Fig. 1). ${ }^{2}$ Other infectious diseases have had significant economic effects worldwide, including several pandemics in the 20th and twenty-first century caused by an influenza virus or a coronavirus. Although the mortality rate for COVID 19 is found to be lower than past epidemics, it has had unprecedented health, social, and economic consequences, given its high contagion rate and global spread. Looking forward, while past pandemics have generally been short lived, how each country comes out of the current crisis will depend on policy choices made during the pandemic, the required adjustment, and the economic and institutional strength prior to COVID-19. Therefore, analyzing the evolution of international tourism flows during past epidemics can shed light on the impact of the COVID 19 pandemic.

Epidemics have always been a fact of life, and the COVID-19 outbreak is not the first infectious disease with profound economic effects across the world. While many factors contribute to the emergence and spread of infectious diseases, cross-border movement of people has always been a potent vector of transmission throughout history (McNeill 1976; Wilson 1991; Wilson 1995; Richter 2003; Snowden 2019). Numerous diseases with epidemic and pandemic potential, including avian flu, cholera, Ebola, malaria, and coronaviruses such as Severe Acute Respiratory Syndrome (SARS), Middle East Respiratory Syndrome (MERS) and now COVID-19, can spread easily through international travel in an increasingly interconnected world and affect consumer behavior and travel patterns at a global scale with far-reaching economic and financial repercussions.

There is a large body of literature on gravity models in international trade, but scarce research on modeling bilateral tourist movements in a gravity framework, especially taking into account the effect of infectious diseases. Most studies in this context look at the impact of disease outbreaks, such as the SARS and avian flu epidemics, on tourism in a specific country or region over a short period of time (Zeng and De Lacy 2005; Cooper 2006; Wilder-Smith 2006; Kuo et al. 2008). This paper is most closely related to Roselló et al. (2017) that analyzes the benefits of eradicating diseases in terms of tourism flows and revenues during the 2000-2013 period, although using dummy variables that do not capture the scale and dynamism of infectious diseases. To learn from past episodes, this paper contributes to the literature by (i) expanding the dataset in terms of country coverage and time-series dimension to 38,184 pairs of countries over the period 1995-2017, (ii) measuring the actual number of confirmed infectiousdisease cases (Ebola, malaria, SARS, and yellow fever) scaled by population, and (iii) estimating the impact on international tourism flows with alternative methodologies, including the pseudo poisson maximum likelihood (PPML), the two-stage least squares (2SLS) with instrumental variable (IV), and the ordinary least squares (OLS), in a gravity framework that controls for macroeconomic factors, geographic and cultural characteristics, and historical ties.

The empirical analysis finds strong evidence that international tourism is adversely affected by the scale and dynamism of infectious diseases and the magnitude of this

\footnotetext{
${ }^{2}$ According to the United Nations World Tourism Organization (WTO), international tourism had grown rapidly from 25 million visitors in 1950 to 440 million by 1990 and over 1.5 billion in 2019, accounting for over $10 \%$ of global GDP and more than 320 million jobs worldwide. Preliminary data indicate that the COVID-19 pandemic already caused a fall of $68 \%$ in international tourist arrivals in the first half of 2020 , compared to the same period of 2019.
} 


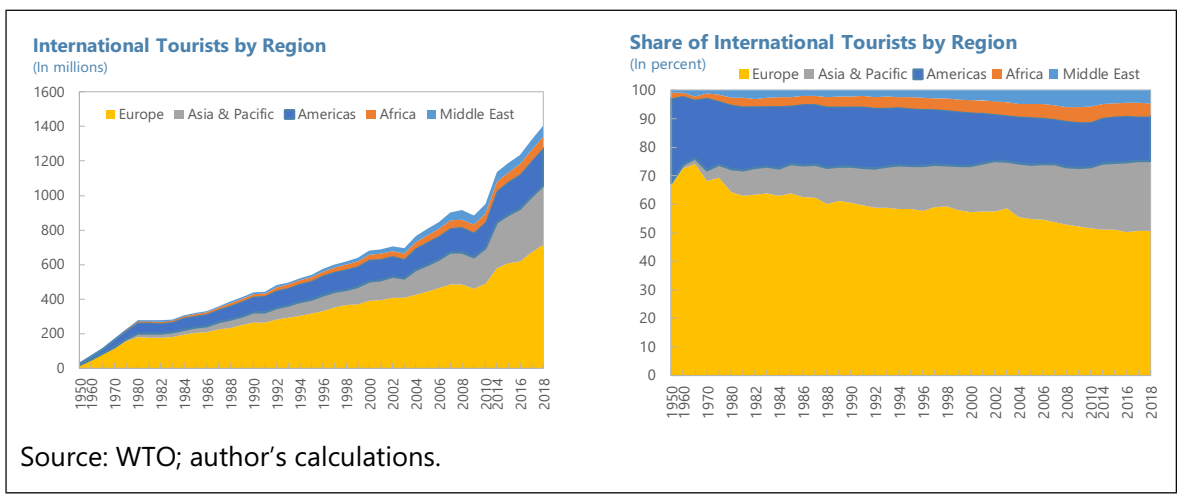

Fig. 1 International Tourism Inflows

negative effect is statistically and economically significant. In the case of SARS, a $10 \%$ increase in the number of confirmed cases leads, on average, to a reduction of $4.7 \%$ in international tourist arrivals across all countries. These results withstand several robustness checks, including alternative specifications and estimation methodologies, to address omitted-variables bias and potential endogeneity. In particular, partitioning the sample into income groups highlights heterogeneity in how the risk of infectious diseases affects international tourism flows. While infectious diseases appear to have a smaller and statistically insignificant negative effect on tourism flows to advanced economies, the magnitude and statistical significance of the impact of infectious diseases are much greater in developing countries, where such diseases tend to be more prevalent and health infrastructure lags behind. Using SARS as an example, the results indicate that a $10 \%$ increase in the number of confirmed infections led to a decline of about $8 \%$ in international tourist arrivals to developing countries - almost twice as much as the average impact on all countries.

The remainder of this study is organized as follows. Section II provides an overview of the data used in the empirical analysis. Section III introduces the salient features of our econometric strategy. Section IV presents the empirical results, including a series of robustness checks. Finally, Section V offers concluding remarks with policy implications.

\subsection{Data Overview}

The empirical analysis presented in this study is based on an unbalanced panel of annual observations for 38,184 pairs of countries during the period 1995$2017 .^{3}$ Bilateral tourism flows for 172 countries of origin and 222 countries of destination are taken from the WTO database, yielding a dataset of over 261,488 observations over the sample period. The main explanatory variable of interest is the number of confirmed infectious-disease cases, including Ebola, malaria, SARS, and yellow fever, which is obtained from the WHO database. Following the literature, real GDP, the real effective exchange rate (REER),

\footnotetext{
${ }^{3}$ The list of countries, including territories, is presented in Appendix Table 4.
} 
population and life expectancy are introduced as control variables, drawn from the IMF's World Economic Outlook (WEO) database and the World Bank's World Development Indicators (WDI) database.

Standard gravity variables such as bilateral distance between countries, common official language, colonial history and geographical contiguity are taken from the Centre d'Etudes Prospectives et d'Informations Internationales (CEPII) database, as presented in Mayer and Zignago (2011). Geographic distance is measured as the great-circle distance in kilometers between the capital cities of each country pair. Binary variables for language, colonial history and geographical contiguity are assigned a value of 1 if a country pair share a common official language, a colonial tie, and an adjacent border and a value of 0 otherwise.

Descriptive statistics for the variables used in the empirical analysis are presented in Table 1. There is a significant degree of dispersion across

Table 1 Summary Statistics

\begin{tabular}{|c|c|c|c|c|c|}
\hline Variables & Obs. & Mean & Std. Dev. & Min. & Max. \\
\hline International tourism flows & 261,488 & 78,737 & 918,199 & 1 & $81,100,000$ \\
\hline \multicolumn{6}{|l|}{ Real GDP } \\
\hline Origin countries & 410,680 & 13,155 & 16,243 & 184 & 111,968 \\
\hline Destination countries & 381,210 & 16,926 & 22,269 & 184 & 194,188 \\
\hline REER, destination & 371,190 & 100.5 & 25.5 & 7.4 & 740.6 \\
\hline Distance & 370,208 & 7273 & 4564 & 27 & 19,951 \\
\hline Common language & 370,208 & 0.173 & 0.378 & 0.000 & 1.000 \\
\hline Colonial history & 370,208 & 0.015 & 0.123 & 0.000 & 1.000 \\
\hline Geographical contiguity & 370,208 & 0.027 & 0.163 & 0.000 & 1.000 \\
\hline Life expectancy, destination & 382,122 & 70.4 & 9.4 & 31.0 & 85.4 \\
\hline \multicolumn{6}{|l|}{ Population } \\
\hline Origin countries & 411,470 & $54,300,000$ & $186,000,000$ & 9298 & $1,390,000,000$ \\
\hline Destination countries & 395,038 & $45,900,000$ & $160,000,000$ & 9298 & $1,400,000,000$ \\
\hline \multicolumn{6}{|l|}{ Infectious diseases } \\
\hline \multicolumn{6}{|l|}{ Origin countries } \\
\hline Ebola & 411,470 & 22 & 496 & 0 & 14,124 \\
\hline Malaria & 411,470 & 69,328 & 631,885 & 0 & $15,000,000$ \\
\hline SARS & 411,470 & 3 & 115 & 0 & 5327 \\
\hline Yellow fever & 411,470 & 3 & 40 & 0 & 1192 \\
\hline \multicolumn{6}{|l|}{ Destination countries } \\
\hline Ebola & 386,101 & 15 & 413 & 0 & 14,124 \\
\hline Malaria & 386,101 & 130,202 & 746,793 & 0 & $15,000,000$ \\
\hline SARS & 386,101 & 3 & 108 & 0 & 5327 \\
\hline Yellow fever & 378,948 & 3 & 34 & 0 & 1192 \\
\hline
\end{tabular}

Source: WTO; IMF; World Bank; WHO; author's calculations 
countries in terms of international tourist flows and considerable heterogeneity in the occurrence of infectious diseases. It is essential to analyze the time-series properties of the data to avoid spurious results by conducting panel unit root tests. Accordingly, the stationarity of all variables is checked by applying the Im et al. (2003) procedure, which is widely used in the empirical literature to conduct a panel unit root test. The results, available upon request, indicate that the variables used in the analysis are stationary after logarithmic transformation.

\subsection{Empirical Methodology}

The gravity model framework is widely used in the economic literature to analyze the patterns of international trade and capital movements, as well as migration and tourism flows (Tinbergen 1962; Anderson and van Wincoop 2003; Bergstrand and Egger 2007; Gil-Pareja et al. 2007; Head and Ries 2008; Santana-Gallego et al. 2010). Bilateral flows between two countries tend to increase with per capita income and decline with transportation costs as proxied by physical distance between the countries. This gives a simple gravity model, in which the number of tourists traveling in one direction between two countries depends on the economic sizes of the countries and the geographical distance between them. Building on Santos Silva and Tenreyro (2006), the baseline gravity specification takes the following form in a panel data context:

$$
\ln \left(T_{i j t}\right)=\beta+\alpha \ln \left(G D P_{i t}\right)+\gamma \ln \left(G D P_{j t}\right)+\vartheta \ln \left(D_{i s t_{i j}}\right)+\eta_{i}+\varphi_{j}+\mu_{t}+\varepsilon_{i j t}
$$

in which $T_{i j}$ denotes international tourist flows between countries $i$ (origin) and $j$ (destination); GDP is the level of per capita income in origin and destination country, respectively; Dist $t_{i j}$ is the physical distance between countries $i$ (origin) and $j$ (destination); the $\eta_{i}, \varphi_{j}$ and $\mu_{t}$ coefficients designate the country fixed effects capturing all time-invariant factors in origin and destination country and the time fixed effects controlling for common shocks that may affect international tourism across all countries in a given year, respectively. $\varepsilon_{i j t}$ is an idiosyncratic error term that meets the standard assumptions of zero mean and constant variance.

Since the objective is to understand the effect of infectious diseases on international tourism, the parsimonious gravity model is augmented with additional control variables along with the number of confirmed infectious-disease cases:

$$
\begin{aligned}
\ln \left(T_{i j t}\right)= & \beta+\alpha \ln \left(G D P_{i t}\right)+\gamma \ln \left(G D P_{j t}\right)+\vartheta \ln \left(D i s t_{i j}\right)+\delta X_{i j t}+\varphi \ln \left(\operatorname{Vir}_{i j t}\right) \\
& +\eta_{i}+\varphi_{j}+\mu_{t}+\varepsilon_{i j t}
\end{aligned}
$$

where $X_{i j t}$ denotes a vector of control variables, including the REER, population, life expectancy, and binary variables for common language, colonial history and geographical contiguity; $V i r_{i j t}$ denotes the number of confirmed cases of Ebola, malaria, SARS, and yellow fever scaled by population in origin 
and destination countries. To account for possible heteroskedasticity, robust standard errors are clustered at the country-pair level. ${ }^{4}$

Most gravity models are estimated with cross-sectional data, which may lead to biased results due to potential correlation between explanatory variables and unobservable country characteristics as it does not control for heterogeneity. Panel data estimations help address such econometric concerns by controlling for country and time fixed effects (Egger 2000). Therefore, in this paper, the gravity model is estimated with the PPML estimator recommended by Santos Silva and Tenreyro (2006) and the 2SLS-IV methodology using the lagged infectious disease as instrument to account for potential endogeneity. ${ }^{5}$

\subsection{Estimation Results}

As a baseline, the gravity model described in Eq. (3) is estimated using the PPML model, which has several important advantages as compared with other estimators by dealing appropriately with heteroscedasticity, model misspecification and excess zeros. Table 2 presents the estimation results starting with a specification including only macroeconomic and demographic variables and standard gravity factors in column (1) as a point of reference. The number of infectious diseases in origin and destination countries is then introduced into the regression in column (2) for Ebola, column (3) for malaria, column (4) for SARS, and column (5) for yellow fever. The results demonstrate a consistent picture with the signs of all estimated parameters corresponding to their expected values across different specifications. Most of the coefficients are highly significant, and the model's performance in terms of goodness of fit is found to be highly satisfactory.

The level of income in both origin and destination countries have a positive impact on bilateral tourism flows, suggesting that international tourism is significantly related to the two countries' economic size. Distance between the countries, on the other hand, is negatively associated with bilateral tourism flows, representing an obstacle for international travel as expected. The greater the distance between the two countries, the smaller the flow of tourists across the two countries, due to higher cost of travel. This is also consistent with the positive effect of the geographical contiguity variable, indicating that tourists tend to travel more to closer destinations. Cultural similarities and historical ties-proxied by common official language and colonial relations, respectively-are found to have the expected positive effects on bilateral tourism flows. Likewise, demographic factors - measured population in origin and destination countries and life expectancy in destination countries-contribute positively to international tourism.

\footnotetext{
${ }_{4}^{4}$ The results remain broadly unchanged when standard errors are clustered at the country level.

5 The gravity model is also estimated using the OLS as a further robustness check, which are available upon request. Since the objective is to include standard time-invariant gravity factors (distance, common language, colonial history, geographical contiguity) in the panel regressions, the OLS model is estimated via the randomeffects regression, instead of the fixed-effects model that would remove time-invariant variables. However, the fixed-effects estimations with origin and destination fixed effects controlling for all possible time-invariant country characteristics yield similar results.
} 
Table 2 Infectious Diseases and International Tourism-PPML Estimations

(Dependent variable: Bilateral tourism flows)

$\begin{array}{llllll} & {[1]} & {[2]} & {[3]} & {[4]} & {[5]} \\ \text { Real GDP, origin } & 0.129^{* * *} & 0.127 * * * & 0.127 * * * & 0.127 * * * & 0.131^{* * *} \\ & {[0.006]} & {[0.006]} & {[0.006]} & {[0.006]} & {[0.006]} \\ \text { Real GDP, destination } & 0.129^{* * *} & 0.129^{* * *} & 0.129^{* * *} & 0.129^{* * *} & 0.132^{* * * *} \\ & {[0.007]} & {[0.008]} & {[0.008]} & {[0.008]} & {[0.008]} \\ \text { Distance } & -0.228^{* * *} & 0.232^{* * *} & 0.231^{* * *} & -0.232^{* * *} & -0.229^{* * *} \\ & {[0.004]} & {[0.004]} & {[0.004]} & {[0.004]} & {[0.004]} \\ \text { Common language } & 0.176^{* * *} & 0.174^{* * *} & 0.174 * * * & 0.174^{* * *} & 0.180^{* * *} \\ \text { Colonial history } & {[0.007]} & {[0.007]} & {[0.007]} & {[0.007]} & {[0.007]} \\ & 0.080^{* * *} & 0.083^{* * *} & 0.083^{* * *} & 0.083^{* *} & 0.076^{* * *} \\ \text { Geographical contiguity } & {[0.016]} & {[0.016]} & {[0.016]} & {[0.016]} & {[0.016]} \\ & 0.034 & 0.035 & 0.035 & 0.035 & 0.031 \\ \text { Population, origin } & {[0.019]} & {[0.016]} & {[0.016]} & {[0.016]} & {[0.016]} \\ & 0.063^{* * *} & 0.065^{* * *} & 0.059^{* * *} & 0.063 * * * & 0.066^{* * *} \\ \text { Population, destination } & {[0.011]} & {[0.011]} & {[0.011]} & {[0.011]} & {[0.011]} \\ & 0.080^{* * *} & 0.078^{* * *} & 0.082^{* * *} & 0.078^{* * *} & 0.084^{* * *} \\ \text { REER, destination } & {[0.012]} & {[0.012]} & {[0.012]} & {[0.013]} & {[0.012]} \\ & 0.000^{* * *} & 0.000^{* * *} & 0.000^{* * *} & 0.000^{* * *} & 0.000^{* * *} \\ \text { Life expectancy, destination } & {[0.000]} & {[0.000]} & {[0.000]} & {[0.000]} & {[0.000]} \\ & 0.097 & 0.103 & 0.113 & 0.091 & 0.088 \\ & {[0.043]} & {[0.043]} & {[0.044]} & {[0.044]} & {[0.043]}\end{array}$

\section{Ebola}

Origin

Destination

Malaria

Origin

0.001

[0.000]

$-0.001$

[0.000]

\section{SARS}

Origin

$-0.003 * * *$

[0.02]

Origin

Yellow fever

Origin

0.003

[0.000]

$-0.001$

Origin

Number of observations

224,019

215,589

Origin FE

Yes

Yes

215,589
Yes

215,589

Yes

Yes 
Table 2 (continued)

\begin{tabular}{lccccc}
\hline Destination FE & Yes & Yes & Yes & Yes & Yes \\
Year FE & Yes & Yes & Yes & Yes & Yes \\
Adjusted $\mathrm{R}^{2}$ & 0.77 & 0.84 & 0.80 & 0.83 & 0.80 \\
\hline
\end{tabular}

Note: The dependent variable is bilateral tourism flows (in log form). Robust standard errors, clustered at the country level, are reported in brackets. A constant is included in each regression, but not shown in the table. *, **, and $* * *$ denote significance at the $10 \%, 5 \%$, and $1 \%$ levels, respectively

With regard to the main explanatory variable of interest, estimation results establish a significant effect of infectious-disease episodes on international tourism flows, but with variation in magnitude and statistical significance depending on the nature of the disease. The estimated coefficients on malaria and yellow fewer are considerably smaller in magnitude, whereas the coefficients on Ebola and SARS are found to be both statistically and economically significant. These results are robust to alternative estimations and specifications, including after controlling for health infrastructure. In the case of SARS, for example, a 10\% increase in the number of confirmed cases leads, on average, to a reduction of $4.7 \%$ in international tourist arrivals (Table 2). There is, however, significant heterogeneity across country groups in the impact of pandemics on tourism, depending on the level of income and health infrastructure.

These estimated differences in how infectious diseases affect international tourism flows likely reflect disease-specific characteristics:

- Vector of transmission. While malaria and yellow fever are transmitted by mosquitoes, Ebola and SARS - similarly to COVID-19 - are spread from human to human. Accordingly, while malaria and yellow fever may be endemic in rural areas, Ebola and SARS could spread more easily in densely populated cities and airports.

- Existence of treatment or vaccine. Although a vaccine for yellow fever and treatments for malaria exist, to the authors' knowledge there is no such treatment or vaccine against Ebola or SARS. Consequently, infection risks of these diseases have a greater effect on international tourism flows, especially to countries with weak health infrastructure.

- Temporary outbreak vs. endemic presence. When a disease is endemic like malaria and yellow fever, there is no point in delaying travel as long as precautions can be taken. Outbreaks of Ebola and SARS, on the other hand, are temporary in nature and, without any treatment or vaccine, incentivize tourists to delay visiting a particular country until the outbreak is over.

The robustness of baseline results is checked by estimating the gravity model alternative specifications and estimation methodologies. First, since tourist arrivals may influence the spread of infectious diseases, the model is estimated with the 2SLS-IV methodology using the lagged infectious disease as an instrument to account for potential endogeneity. Second, the sample is truncated at the 5th and 95th percentiles to remove the potential impact of extreme outliers. Third, the gravity model is estimated for a subsample of 1995-2007 to exclude the period after the global financial crisis. Fourth, an additional health-related control variables - the number of hospital beds per 1000 people - is introduced to address omitted-variable bias and capture the impact of health 
infrastructure. To exhibit a concise table, some of these robustness checks are presented only for SARS, but the results remain consistent for other infectious diseases.

The 2SLS-IV estimation, presented in Table 3, increases the magnitude of the cumulative coefficient on the infectious disease (SARS) - to - 0.465 compared to -0.043 in the baseline estimation, strongly supporting the contemporaneous impact of infectious diseases on international travel both in terms of magnitude and statistical significance. Other robustness checks, presented in Appendix Table 5, show that the negative and economically significant relationship between infectious diseases and international tourism flows remains unchanged in the context of 38,184 pairs of countries during the period 1995-2017, with some changes in the magnitude of estimated coefficients. Estimating the model with the truncated sample and for the period excluding the global financial crisis yields higher coefficients on the infectiousdisease variable. Adding the number of hospital beds into the regression model reveals that health infrastructure in destination countries matter for bilateral tourism flows.

Finally, partitioning the sample into income groups and geographical regions highlights heterogeneity on how the risk of infectious diseases affects international tourism flows. These estimation results, presented in Appendix Table 6, show a substantial contrast between advanced economies and developing countries. Although infectious diseases appear to have statistically insignificant effect on tourism flows to advanced economies, the magnitude and statistical significance of the impact of infectious diseases are much greater in developing countries, where such diseases tend to be more prevalent and health infrastructure lags behind. ${ }^{6}$ For example, in the case of SARS, a $10 \%$ increase in the number of confirmed infections led to a decline of about $8 \%$ in international tourist arrivals to developing countries - almost twice as much as the average impact on all countries. These findings show systemic differences among geographical regions: the disease impact on international tourism flows is significantly greater in Asia, Latin America, and the Caribbean than the rest of the world.

\section{Conclusion}

How and to what extent do infectious diseases affect international tourism? This paper develops a gravity model of bilateral tourist flows among 38,184 country pairs over the period 1995-2017 to provide an empirical answer to these questions using previous infectious-disease episodes. The empirical analysis provides strong evidence that international tourism is adversely affected by the risk of infectious diseases as measured by the number of confirmed cases in past episodes. The magnitude of this negative effect is statistically and economically greater for Ebola and SARS, which are transmitted from human to human, unlike malaria and yellow fever. With no treatment or vaccine against Ebola and SARS, contagion risks of these infectious diseases have a greater impact on tourism flows. Consistently, in the case of SARS, a $10 \%$ increase in the number of confirmed cases leads, on average, to a reduction of $4.7 \%$ in international tourist arrivals across all countries. These results withstand several robustness checks,

\footnotetext{
${ }^{6}$ Unlike past episodes, however, the impact of COVID-19 on tourism flows will be similar across all country groups, given the extent of containment measures put in place by all countries regardless the level of income.
} 
Table 3 Infectious Diseases and International Tourism-2SLS-IV Estimations

(Dependent variable: Bilateral tourism flows)

\begin{tabular}{|c|c|c|c|c|}
\hline & {$[1]$} & {$[2]$} & {$[3]$} & {$[4]$} \\
\hline \multirow[t]{2}{*}{ Real GDP, origin } & $0.933 * * *$ & $0.935 * * *$ & $0.959 * * *$ & $0.957 * * *$ \\
\hline & {$[0.012]$} & {$[0.012]$} & {$[0.014]$} & {$[0.012]$} \\
\hline \multirow[t]{2}{*}{ Real GDP, destination } & $0.865^{* * *} *$ & $0.856^{* * *}$ & $0.861 * * *$ & $0.896 * * *$ \\
\hline & {$[0.013]$} & {$[0.013]$} & {$[0.015]$} & {$[0.013]$} \\
\hline \multirow[t]{2}{*}{ Distance } & $-1.717 * * *$ & $-1.717 * * *$ & $-1.716^{* * *}$ & $-1.717 * * *$ \\
\hline & {$[0.015]$} & {$[0.015]$} & {$[0.015]$} & {$[0.015]$} \\
\hline \multirow[t]{2}{*}{ Common language } & $1.241 * * *$ & $1.241 * * *$ & $1.241 * * *$ & $1.272 * * *$ \\
\hline & {$[0.034]$} & {$[0.034]$} & {$[0.034]$} & {$[0.034]$} \\
\hline \multirow[t]{2}{*}{ Colonial history } & $0.849 * * *$ & $0.850 * * *$ & $0.850 * * *$ & $0.832 * * *$ \\
\hline & {$[0.086]$} & {$[0.086]$} & {$[0.086]$} & {$[0.084]$} \\
\hline \multirow[t]{2}{*}{ Geographical contiguity } & $1.210^{* * *}$ & $1.207 * * *$ & $1.208 * * *$ & $1.163^{* * *}$ \\
\hline & {$[0.067]$} & {$[0.067]$} & {$[0.067]$} & {$[0.066]$} \\
\hline \multirow[t]{2}{*}{ Population, origin } & $0.523^{* * *} *$ & $0.517 * * *$ & $0.514 * * *$ & $0.498 * * *$ \\
\hline & {$[0.022]$} & {$[0.023]$} & {$[0.023]$} & {$[0.022]$} \\
\hline \multirow[t]{2}{*}{ Population, destination } & $0.526^{* * *} *$ & $0.562 * * *$ & $0.514 * * *$ & $0.576^{* * *}$ \\
\hline & {$[0.023]$} & {$[0.024]$} & {$[0.024]$} & {$[0.022]$} \\
\hline \multirow[t]{2}{*}{ REER, destination } & $0.001 * * *$ & $0.001 * * *$ & $0.001 * * *$ & $0.001 * * *$ \\
\hline & {$[0.000]$} & {$[0.000]$} & {$[0.000]$} & {$[0.000]$} \\
\hline \multirow[t]{2}{*}{ Life expectancy, destination } & 0.097 & 0.039 & 0.214 & 0.209 \\
\hline & {$[0.070]$} & {$[0.078]$} & {$[0.081]$} & {$[0.068]$} \\
\hline
\end{tabular}

\section{Ebola}

Origin

$-0.065 * * *$

[0.005]

Destination

$-0.089 * * *$

[0.008]

\section{Malaria}

Origin

$-0.001$

[0.001]

Destination

$-0.007$

[0.001]

\section{SARS}

Origin

$-0.387 * * *$

[0.092]

Destination

$-0.078 * * *$

[0.104]

Yellow fever

Origin

Destination 
Table 3 (continued)

(Dependent variable: Bilateral tourism flows)

\begin{tabular}{lcccc}
\hline Origin FE & Yes & Yes & Yes & Yes \\
Destination FE & Yes & Yes & Yes & Yes \\
Year FE & Yes & Yes & Yes & Yes \\
Pseudo R & 0.83 & 0.83 & 0.83 & 0.84 \\
\hline
\end{tabular}

Note: The dependent variable is bilateral tourism flows (in log form). Robust standard errors, clustered at the country level, are reported in brackets. A constant is included in each regression, but no shown in the table *, $* *$, and $* * *$ denote significance at the $10 \%, 5 \%$, and $1 \%$ levels, respectively

including alternative specifications and estimation methodologies, to address omittedvariable bias and account for potential endogeneity.

There is, however, significant heterogeneity across country groups in the impact of pandemics on tourism, depending on the level of income and health infrastructure. Partitioning the sample into income groups and geographical regions shows a substantial contrast between advanced economies and developing countries. Although infectious diseases appear to have statistically insignificant effect on tourism flows to advanced economies, the magnitude and statistical significance of the impact of infectious diseases are much greater in developing countries, where such diseases tend to be more prevalent and health infrastructure lags behind. For example, in the case of SARS, a $10 \%$ increase in the number of confirmed infections leads to a decline of about $8 \%$ in international tourist arrivals to developing countries - almost twice as much as the average impact on all countries. These findings show systemic differences among geographical regions: the disease impact on international tourism flows is significantly greater in Asia, Latin America, and the Caribbean than the rest of the world.

There are two important dimensions highlighted by this analysis: (i) the geographical disparity in international tourism flows and (ii) availability of treatment and preventive medicine. As of 2019 , over $50 \%$ of international tourist arrivals worldwide were bound for to Europe, while the share of other regions remained relatively small. In particular, Africa accounted for $4.8 \%$ of international tourist arrivals, barely increasing over the past two decades. On the other hand, tourism in Asia grew rapidly to $24.5 \%$ of international tourist arrivals, from $12.8 \%$ in 1990 and $3.7 \%$ in 1970 . Consequently, infectious diseases originating from Asia - like SARS and now COVID-19 — can have a profound effect on international travel, especially considering the lack of treatment options and preventive medicine. Further, the COVID-19 outbreak is the first truly global pandemic in modern times, reaching every corner of the world and making geographical differentiation impossible for tourism. The collapse of international travel is therefore not an unexpected outcome of the COVID19 pandemic that has had grave public health repercussions throughout the world. ${ }^{7}$ Scaling the estimated coefficient of SARS to the prevalence of COVID-19 as measured by the number of confirmed cases in population would yield an approximate decline of $82.5 \%$ in international tourism flows worldwide, which is broadly consistent with the actual impact of $-65 \%$ registered in the first half of 2020 .

\footnotetext{
${ }^{7}$ Based on preliminary data, the WTO expects international tourist arrivals to decline by more than $80 \%$ in 2020 , due to the closure of borders, travel bans, and containment measures put in place in many countries to slow the spread of COVID-19.
} 


\section{Appendix}

Table 4 List of Countries and Territories

\begin{tabular}{|c|c|c|c|}
\hline Afghanistan & Denmark & Liberia & Rwanda \\
\hline Albania & Djibouti & Libya & Saba \\
\hline Algeria & Dominica & Liechtenstein & Saint Eustatius \\
\hline American Samoa & $\begin{array}{l}\text { Dominican } \\
\text { Republic }\end{array}$ & Lithuania & Saint Maarten \\
\hline Andorra & Ecuador & Luxembourg & Samoa \\
\hline Angola & Egypt & Macao SAR & San Marino \\
\hline Anguilla & El Salvador & Madagascar & Sao Tome And Principe \\
\hline Antigua And Barbuda & Equatorial Guinea & Malawi & Saudi Arabia \\
\hline Argentina & Eritrea & Malaysia & Senegal \\
\hline Armenia & Estonia & Maldives & Serbia \\
\hline Aruba & Eswatini & Mali & Seychelles \\
\hline Australia & Ethiopia & Malta & Sierra Leone \\
\hline Austria & Fiji & Marshall Islands & Singapore \\
\hline Azerbaijan & Finland & Martinique & Slovak Republic \\
\hline Bahamas, The & France & Mauritania & Slovenia \\
\hline Bahrain & French Guiana & Mauritius & Solomon Islands \\
\hline Bangladesh & French Polynesia & Mexico & Somalia \\
\hline Barbados & Gabon & Micronesia & South Africa \\
\hline Belarus & Gambia, the & Moldova & South Sudan \\
\hline Belgium & Georgia & Monaco & Spain \\
\hline Belize & Germany & Mongolia & Sri Lanka \\
\hline Benin & Ghana & Montenegro & St. Kitts and Nevis \\
\hline Bermuda & Greece & Montserrat & St. Lucia \\
\hline Bhutan & Grenada & Morocco & $\begin{array}{l}\text { St. Vincent and the } \\
\text { Grenadines }\end{array}$ \\
\hline Bolivia & Guadeloupe & Mozambique & Sudan \\
\hline Bonaire & Guam & Myanmar & Suriname \\
\hline Bosnia And Herzegovina & Guatemala & Namibia & Sweden \\
\hline Botswana & Guinea & Nauru & Switzerland \\
\hline Brazil & Guinea-Bissau & Nepal & Syria \\
\hline British Virgin Islands & Guyana & Netherlands & Taiwan Province of China \\
\hline Brunei Darussalam & Haiti & New Caledonia & Tajikistan \\
\hline Bulgaria & Honduras & New Zealand & Tanzania \\
\hline Burkina Faso & Hong Kong SAR & Nicaragua & Thailand \\
\hline Burundi & Hungary & Niger & Timor-Leste \\
\hline Cabo Verde & Iceland & Nigeria & Togo \\
\hline Cambodia & India & Niue & Tonga \\
\hline Cameroon & Indonesia & North Korea & Trinidad And Tobago \\
\hline
\end{tabular}


Table 4 (continued)

\begin{tabular}{llll}
\hline Afghanistan & Denmark & Liberia & Rwanda \\
\hline Canada & Iran & North Macedonia & Tunisia \\
Cayman Islands & Iraq & Northern Mariana & Turkey \\
Central African Republic & Ireland & Islands & \\
Chad & Israel & Oman & Turkmenistan \\
Chile & Italy & Pakistan & Turks And Caicos Islands \\
China & Jamaica & Palau & Tuvalu \\
Colombia & Japan & Palestine & Uganda \\
Comoros & Jordan & Panama & Ukraine \\
Congo, Republic of & Kazakhstan & Papua New Guinea & United Kingdom \\
Cook Islands & Kenya & Paraguay & United States \\
Costa Rica & Kiribati & Peru & United States Virgin Islands \\
Côte d'Ivoire & Korea & Philippines & Uruguay \\
Croatia & Kuwait & Poland & Uzbekistan \\
Cuba & Kyrgyz Republic & Portugal & Vanuatu \\
Curacao & Lao P.D.R. & Puerto Rico & Venezuela \\
Cyprus & Latvia & Qatar & Vietnam \\
Czech Republic & Lebanon & Reunion & Yemen \\
Democratic Republic Of The & Lesotho & Romania & Zambia \\
Congo & & & \\
\hline & & & \\
\hline & & & Onirates \\
\hline
\end{tabular}


Table 5 Infectious Diseases and Tourism-Robustness Checks

(Dependent variable: Bilateral tourism flows)

\begin{tabular}{|c|c|c|c|}
\hline & Truncated sample & Sub-sample (1995-2007) & Additional controls \\
\hline \multirow[t]{2}{*}{ Real GDP, origin } & $0.961 * * *$ & $1.259 * * *$ & $1.023 * * *$ \\
\hline & {$[0.013]$} & {$[0.028]$} & {$[0.018]$} \\
\hline \multirow[t]{2}{*}{ Real GDP, destination } & $0.808 * * *$ & $0.751 * * *$ & $0.967 * * *$ \\
\hline & {$[0.015]$} & {$[0.028]$} & [0.019] \\
\hline \multirow[t]{2}{*}{ Distance } & $-1.632 * * *$ & $-1.688 * * *$ & $-1.704 * *$ \\
\hline & {$[0.015]$} & {$[0.021]$} & {$[0.018]$} \\
\hline \multirow[t]{2}{*}{ Common Language } & $1.202 * * *$ & $1.170 * * *$ & $1.233 * * *$ \\
\hline & {$[0.033]$} & {$[0.046]$} & [0.039] \\
\hline \multirow[t]{2}{*}{ Colonial history } & $0.755 * * *$ & $0.919 * * *$ & $0.864 * * *$ \\
\hline & {$[0.089]$} & {$[0.106]$} & {$[0.093]$} \\
\hline \multirow[t]{2}{*}{ Geographical contiguity } & $1.116 * * *$ & $1.232 * * *$ & $1.261 * *$ \\
\hline & {$[0.072]$} & {$[0.084]$} & {$[0.074]$} \\
\hline \multirow[t]{2}{*}{ Population Origin } & $0.478 * *$ & $1.224 * * *$ & $0.554 * * *$ \\
\hline & {$[0.022]$} & {$[0.057]$} & {$[0.033]$} \\
\hline \multirow[t]{2}{*}{ Population destination } & $0.478 * *$ & $0.305 * * *$ & $0.625 * * *$ \\
\hline & {$[0.023]$} & {$[0.057]$} & {$[0.032]$} \\
\hline \multirow[t]{2}{*}{ REER, destination } & $0.001 * *$ & $0.001 * *$ & $0.001 * *$ \\
\hline & {$[0.000]$} & {$[0.000]$} & {$[0.000]$} \\
\hline \multirow[t]{2}{*}{ Life expectancy, destination } & 0.151 & 0.060 & $0.711 * * *$ \\
\hline & {$[0.078]$} & {$[0.136]$} & [0.194] \\
\hline \multirow[t]{2}{*}{ Hospital beds, destination } & & & $0.027 * * *$ \\
\hline & & & {$[0.010]$} \\
\hline \multicolumn{4}{|l|}{ SARS } \\
\hline \multirow[t]{2}{*}{ Origin } & $-0.224 * * *$ & $-0.281 * * *$ & $-0.224 * * *$ \\
\hline & {$[0.085]$} & {$[0.041]$} & {$[0.095]$} \\
\hline \multirow[t]{2}{*}{ Destination } & $-0.028 * * *$ & $-0.016^{* * *}$ & $-0.011 * * *$ \\
\hline & {$[0.091]$} & {$[0.050]$} & {$[0.103]$} \\
\hline Number of observations & 179,489 & 96,416 & 111,519 \\
\hline Origin FE & Yes & Yes & Yes \\
\hline Destination FE & Yes & Yes & Yes \\
\hline Year FE & Yes & Yes & Yes \\
\hline Adjusted $\mathrm{R}^{2}$ & 0.79 & 0.83 & 0.83 \\
\hline
\end{tabular}

Note: The dependent variable is bilateral tourism flows (in log form). Robust standard errors, clustered at the country level, are reported in brackets. A constant is included in each regression, but no shown in the table *, $* *$, and $* * *$ denote significance at the $10 \%, 5 \%$, and $1 \%$ levels, respectively 
Table 6 Infectious Diseases and Tourism-Income Group and Region

(Dependent variable: Bilateral tourism flows)

\begin{tabular}{|c|c|c|c|c|c|c|c|}
\hline \multirow[b]{2}{*}{ America } & Advanced & Developing & Africa & Asia & Europe & Latin & \\
\hline & $\begin{array}{r}\text { Middle } \\
\text { East }\end{array}$ & & & & & & \\
\hline \multirow[t]{2}{*}{ Real GDP, origin } & $1008 * * *$ & $0.935^{* * *}$ & $0.860 * * *$ & $1.044 * * *$ & $0.754 * * *$ & $0.889 * * *$ & $1.169 * * *$ \\
\hline & {$[0.017]$} & {$[0.020]$} & {$[0.044]$} & {$[0.054]$} & {$[0.44]$} & {$[0.035]$} & {$[0.052]$} \\
\hline \multirow{2}{*}{$\begin{array}{l}\text { Real GDP, } \\
\text { destination }\end{array}$} & $1.083^{* * *}$ & $0.744 * * *$ & $0.304 * * *$ & $1.201 * * *$ & $0.575 * * *$ & $0.744 * * *$ & $0.371 * * *$ \\
\hline & {$[0.44]$} & {$[0.024]$} & {$[0.040]$} & {$[0.077]$} & {$[0.045]$} & {$[0.047]$} & {$[0.060]$} \\
\hline \multirow[t]{2}{*}{ Distance } & $-1.351^{* * *}$ & $-1.821 * * *$ & $-1.512 * * *$ & $-1.932 * * *$ & $-1.518 * * *$ & $-1.737 * * *$ & $-1482 * * *$ \\
\hline & {$[0.026]$} & {$[0.019]$} & {$[0.053]$} & {$[0.077]$} & {$[0.085]$} & {$[0.051]$} & {$[0.072]$} \\
\hline \multirow{2}{*}{$\begin{array}{l}\text { Common } \\
\text { Language }\end{array}$} & $0.584 * * *$ & $1.404 * * *$ & $1.170 * * *$ & $0.697 * * *$ & 0.863 & $1.451 * * *$ & $0.781 * * *$ \\
\hline & {$[0.054]$} & {$[0.040]$} & {$[0.058]$} & {$[0.112]$} & {$[0.406]$} & {$[0.064]$} & {$[0.126]$} \\
\hline \multirow[t]{2}{*}{ Colonial history } & $1.164 * * *$ & $0.848 * * *$ & 0.231 & $1.113^{* *}$ & 0.109 & 0.541 & 0.526 \\
\hline & {$[0.082]$} & {$[0.146]$} & [0.499] & [0.409] & {$[0.208]$} & {$[0.529]$} & {$[0.388]$} \\
\hline \multirow{2}{*}{$\begin{array}{c}\text { Geographical } \\
\text { contiguity }\end{array}$} & $0.480^{* * *}$ & $1.307 * * *$ & $1.126^{* * *}$ & $0.936^{* * *}$ & $1.525^{* * *}$ & $0.970 * * *$ & $1.662 * * *$ \\
\hline & {$[0.106]$} & {$[0.079]$} & {$[0.148]$} & {$[0.185]$} & {$[0.167]$} & {$[0.150]$} & {$[0.198]$} \\
\hline \multirow[t]{2}{*}{ Population, origin } & $0.219^{* * *}$ & $0.660 * * *$ & $1.010 * * *$ & $0.824 * * *$ & $0.860 * * *$ & $0.797 * * *$ & 0.156 \\
\hline & {$[0.030]$} & {$[0.031]$} & {$[0.065]$} & {$[0.084]$} & {$[0.068]$} & {$[0.060]$} & {$[0.084]$} \\
\hline \multirow{2}{*}{$\begin{array}{l}\text { Population, } \\
\text { destination }\end{array}$} & $0.231 * * *$ & $0.433 * * *$ & $0.398 * * *$ & 0.392 & 0.316 & $0.729 * * *$ & $0.885^{* * *}$ \\
\hline & {$[0.063]$} & {$[0.031]$} & {$[0.133]$} & {$[0.179]$} & {$[0.148]$} & {$[0.114]$} & {$[0.065]$} \\
\hline \multirow[t]{2}{*}{ REER, destination } & $0.006^{* * *}$ & $-0.000 * * *$ & 0.000 & $-0.002 * * *$ & 0.000 & $0.000 * * *$ & 0.000 \\
\hline & {$[0.000]$} & {$[0.000]$} & {$[0.000]$} & {$[0.001]$} & {$[0.000]$} & {$[0.000]$} & {$[0.000]$} \\
\hline \multirow{2}{*}{$\begin{array}{l}\text { Life expectancy, } \\
\text { destination }\end{array}$} & $5.847 * * *$ & $0.585^{* * *}$ & $0.366^{*}$ & $1.668^{* *}$ & $3.911 * * *$ & 0.745 & 0.887 \\
\hline & {$[0.528]$} & {$[0.087]$} & {$[0.146]$} & {$[0.554]$} & [1.264] & {$[0.420]$} & {$[0.659]$} \\
\hline \multicolumn{8}{|l|}{ SARS } \\
\hline \multirow[t]{2}{*}{ Origin } & -0.472 & $-0.556^{* * *}$ & -0.362 & $-0.993^{* * *}$ & -0.144 & $-0.455^{* *}$ & $-0.850^{*}$ \\
\hline & {$[0.136]$} & {$[0.120]$} & {$[0.221]$} & {$[0.315]$} & {$[0.322]$} & [0.219] & {$[0.331]$} \\
\hline \multirow[t]{2}{*}{ Destination } & -0.246 & $-0.243 * * *$ & -0.207 & $-0.311 * * *$ & -0.761 & -0.204 & -0.229 \\
\hline & {$[0.110]$} & {$[0.091]$} & {$[0.544]$} & {$[0.191]$} & {$[1.505]$} & {$[0.630]$} & {$[0.371]$} \\
\hline $\begin{array}{l}\text { Number of } \\
\text { observations }\end{array}$ & 70,721 & 139,500 & 36,232 & 23,922 & 23,794 & 33,750 & 21,802 \\
\hline Origin FE & Yes & Yes & Yes & Yes & Yes & Yes & Yes \\
\hline Destination FE & Yes & Yes & Yes & Yes & Yes & Yes & Yes \\
\hline Year FE & Yes & Yes & Yes & Yes & Yes & Yes & Yes \\
\hline Adjusted $\mathrm{R}^{2}$ & 0.88 & 0.85 & 0.81 & 0.86 & 0.85 & 0.85 & 0.81 \\
\hline
\end{tabular}

Note: The dependent variable is bilateral tourism flows (in log form). Robust standard errors, clustered at the country level, are reported in brackets. A constant is included in each regression, but no shown in the table *, $* *$, and $* * *$ denote significance at the $10 \%, 5 \%$, and $1 \%$ levels, respectively 
Acknowledgements The author would like to thank the editor, George Tavlas, and two anonymous referees for their insightful comments that helped improve the paper. An earlier version of this article benefited from comments and suggestions Federico Diez, Manuela Goretti, Salma Khalid, Margaux MacDonald, Marina Marinkov, Samuel Pienknagura, Cyril Rebillard, Luca Ricci, Jorge Salas, Fatih Yilmaz, and participants of a seminar at the Western Hemisphere Department of the International Monetary Fund (IMF) for insightful comments and suggestions, and Rahul Ainapur, Ben Sutton and Tianle Zhu for excellent assistance in data collection and management. The views expressed herein are those of the author and should not be attributed to the IMF, its Executive Board, or its management.

Data Availability Statement The data that support the findings of this study are available at the World Trade Organization and the World Health Organization and in the IMF's International Financial Statistics and World Economic Outlook databases, and the World Bank's World Development Indicators database.

\section{Declarations}

Conflict of Interest The author states that there is no conflict of interest.

\section{References}

Anderson J, van Wincoop E (2003) Gravity with gravitas: a solution to the border puzzle. Am Econ Rev 93: $170-192$

Bergstrand J, Egger P (2007) A knowledge-and-physical-capital model of international trade, Foreign Direct Investment, and Foreign Affiliates Sales: Developed Countries. Journal of International Economics 73:278-308

Cooper M (2006) Japanese tourism and the SARS epidemic of 2003. Journal of Travel and Tourism Marketing 19:117-131

Egger P (2000) A note on the proper econometric specification of the gravity equation. Econ Lett 66:25-31

Head K, Ries J (2008) FDI as an outcome of the market for corporate control: theory and evidence. J Int Econ 74:2-20

Gil-Pareja S, Llorca-Vivero R, Martínez-Serrano J (2007) The effect of EMU on tourism. Rev Int Econ 15:302-312

Im K, Pesaran M, Shin Y (2003) Testing for unit roots in heterogeneous panels. J Econ 115:53-74

Kuo H-I, Chen C-C, Tseng W-C, Ju L-F, Huang B-W (2008) Assessing impacts of SARS and avian flu on international tourism demand to Asia. Tour Manag 29:917-928

Mayer T, Zignago S (2011) "Notes on CEPII's Distance Measures: The GeoDist Database," CEPII Working Paper No. 2011-25. Centre d'Etudes Prospectives et d'Informations Internationales, Paris

McNeill W (1976) Plagues and people. Anchor Press/Doubleday, New York

Richter L (2003) International tourism and its global public health consequences. Tour Manag 27:361-393

Roselló J, Santana-Gallego M, Awan W (2017) Infectious disease risk and international tourism demand. Health Policy Plan 32:538-548

Santana-Gallego M, Ledesma-Rodríguez F, Pérez-Rodríguez J (2010) Exchange rate regimes and tourism. Tour Econ 16:25-43

Santos Silva J, Tenreyro S (2006) The log of gravity. Rev Econ Stat 88:641-658

Snowden F (2019) Epidemics and society: from the black death to the present. Yale University Press, New Haven, Con

Tinbergen J (1962) Shaping the world economy: suggestions for an international economic policy. The International Executive 5:27-30

Wilder-Smith A (2006) The severe acute respiratory syndrome: impact on travel and tourism. Travel Medicine and Infectious Diseases 4:53-60

Wilson M (1991) A world guide to infections: diseases, distribution, diagnosis. Oxford University Press, New York Wilson M (1995) Travel and the emergence of infectious diseases. Emerg Infect Dis 1:39-46

Zeng, B., R-W. Carter, and T. De Lacy, 2005, "Short-term perturbations and tourism effects: the case of SARS in China," Curr Issue Tour, Vol. 8, pp. 306-322

Publisher's Note Springer Nature remains neutral with regard to jurisdictional claims in published maps and institutional affiliations. 